\title{
Application of Factorial Design and Response Surface Methods to Optimize Ethyl Biodiesel Production from Corn Oil
}

\author{
de Lima A. P.; ${ }^{*}$ de Lima A. L.; Santos D. Q.; Neto W. B.
}

Rev. Virtual Quim., 2013, 5 (5), 817-827. Data de publicação na Web: 30 de setembro de 2013

http://www.uff.br/rvq

\section{Aplicação do Planejamento Fatorial e Método da Superfície de Resposta para Otimizar a Produção de Biodiesel Etílico de Óleo de Milho}

Resumo: Neste estudo foram investigadas, aplicando fatorial fracionário e composto central, as variáveis da reação de transesterificação de óleo de milho usando álcool etílico: (i) tempo de reação, (ii) velocidade de agitação, (iii) razão molar etanol: óleo, (iv) tipo de catalisador, (v) concentração do catalisador e (vi) temperatura. O objetivo é otimizar as condições do processo, a fim de alcançar a máxima eficiência da reação de transesterificação e avaliar o efeito de cada uma das variáveis e as interações entre elas no rendimento. Após a escala de bancada foi realizada a caracterização físico-química do biodiesel etílico obtido de milho por transesterificação alcalina na melhor condição e que se encaixa nos parâmetros analisados de acordo com as especificações da Agência Nacional do Petróleo, Gás Natural e Biocombustíveis (ANP), Sociedade Americana de Testes e Materiais (ASTM) e Comitê Europeu de Normalização (EN).

Palavras-chave: Biodiesel; transesterificação; planejamento experimental; óleo de milho.

\section{Abstract}

In this study were investigated, by applying fractional factorial and central composite, and the variables of the reaction of transesterification of corn oil using ethyl alcohol: (i) reaction time, (ii) agitation speed, (iii) molar ratio ethanol: oil, (iv) type of catalyst, (v) concentration of the catalyst and (vi) temperature. The goal is to optimize the process conditions in order to achieve maximum efficiency of the transesterification reaction and evaluate the effect of each variable and their interactions on yield. After bench scale was performed physicochemical characterization of ethyl biodiesel of corn in the best condition, and that fits the parameters analyzed in accordance with the specifications of the National Agency of Petroleum, Natural Gas and Biofuels (ANP) American Society for Testing and Materials (ASTM) and European Committee for Standardization (EN).

Keywords: Biodiesel; transesterification; experimental design; corn oil.

\footnotetext{
* Universidade Federal de Uberlândia, Instituto de Química, Campus Santa Monica, CEP 38408-100 Uberlândia-MG, Brasil. Tel./fax: +55 3432394425

$M$ analimaquimica@gmail.com

DOI: $\underline{10.5935 / 1984-6835.20130059}$
} 


\title{
Application of Factorial Design and Response Surface Methods to Optimize Ethyl Biodiesel Production from Corn Oil
}

\author{
Ana Paula de Lima, ${ }^{\mathrm{a}, *}$ Ana Lucia de Lima, ${ }^{\mathrm{a}}$ Douglas Q. Santos, ${ }^{\mathrm{b}}$ Waldomiro \\ B. Neto ${ }^{a}$ \\ ${ }^{a}$ Universidade Federal de Uberlândia, Instituto de Química, Campus Santa Monica, Avenida \\ João Naves de Ávila 2121, 38408-100 Uberlândia, Minas Gerais, Brasil.

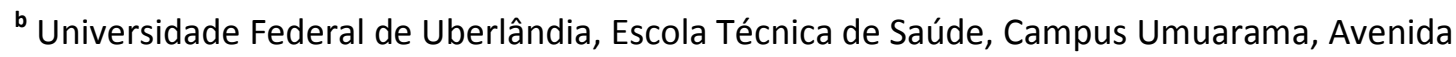 \\ Amazonas, s/n. 38408-100 Uberlândia, Minas Gerais, Brasil.
}

*analimaquimica@gmail.com

\section{Introduction}

\section{Material e methods}

2.1. Reagents and Materials

2.2. Transesterification Reaction

\subsection{Statistical Methods}

\section{Results and discussion}

\section{Conclusions}

\section{Introduction}

The use of biodiesel in the Brazilian energy grid began in 2008 with a mixture of $2 \%(\mathrm{v} / \mathrm{v})$ of biodiesel in diesel, a mixture known as B2, implemented through legislation via Law 11.097/2005. ${ }^{1}$ Biodiesel can be produced from waste materials, grease and agricultural products including corn oil. ${ }^{2-7}$ At the beginning of 2010 the Brazilian National Agency of Petroleum, Natural Gas and Biofuels (ANP) established that all diesel fuel marketed in the country must contain $5 \%(\mathrm{v} / \mathrm{v})$ of added biodiesel (B5), as this mixture will reduce by $3 \%$ the carbon dioxide emitted from the fuel burning. ${ }^{8}$

Maize is cultivated in several regions of Brazil, both by small land holders and by large agricultural producers, with significant participation in the national economy and export market. ${ }^{9}$ It is a crop of high production with diverse uses in modern society and one of the most widely distributed crops in the world, both in terms of production and consumption. ${ }^{10,11}$ of the species grown to produce oil, corn is certainly one of the biggest in the world economy, and in Brazil it is the second most important grain, both in terms of sown area and production, currently second only to soybean. ${ }^{9}$

On average, 172 liters of oil are extracted for each hectare of corn, which makes this a

Rev. Virtual Quim. |Vol 5| |No.5 | |817-827| 
potential oil crop feedstock for biofuel production. ${ }^{7,12,13}$ According to statistics published by the Brazilian Agricultural Ministry in 2010, the area reserved for the planting of corn increased by $11.4 \%$ in 2009 compared with $2008^{14}$ and according to the Brazilian Ministry of Development, Industry and Foreign Trade the corn export volume reached 1.087 million tons in 2009, an increase of $40.4 \%$ compared to $2008 .{ }^{15}$

The percentage of unsaturated fatty acids in corn oil is $88 \%$, giving it a high oxidative stability. ${ }^{7,}$ Among other properties, it also has less than $0.5 \%$ acidity and a high flash point. These properties are directly related to safety during the transport and storage of biofuel ${ }^{17}$ and make its use very favorable in an alkaline transesterification process. ${ }^{16,18}$

Biodiesel can be obtained by transesterification of oil by methanolysis or ethanolysis, ${ }^{19}$ the reactivity and the separation between the biodiesel and glycerin phases being more efficient with the use of methanol. The production of biodiesel through the ethylic route, from the environmental point of view, is more attractive because ethanol can be obtained from renewable sources. However, it is important to consider that methanol can also be produced from biomass, and thus the supposed ecological advantage and positive environmental issues can be outweighed. ${ }^{20}$ Currently, the choice between these two products is related to the availability and price of each alcohol.

In this study, we used a fractional factorial design to screen the variables and the response surface central composite design (CCD) to optimize the reaction parameters to give the best yield in the production of biodiesel from corn by transesterification via the ethylic route with alkaline catalysis. Both the corn oil and the biodiesel obtained were characterized according to their physicochemical properties.

\section{Material and methods}

\subsection{Reagents and Materials}

Refined corn oil obtained from a local market, absolute ethanol PA (Dynamic, 99.8\%) and potassium hydroxide PA (Vetec ${ }^{\circledR}$ $85 \%$ ) and sodium hydroxide PA (Isofar ${ }^{\circledR}$ >99\%) were used for the alkaline transesterification reaction. The characterization of the oil and biodiesel were performed using a Metrohm ${ }^{\circledR}$ automatic potentiometric titrator (model 808); $\mathrm{ABBE}^{\circledR}$ Refractometer; Metrohm ${ }^{\circledR}$ coulometric Karl Fischer titrator (model $831 \mathrm{KF}$ ), Kyoto ${ }^{\circledR}$ densimeter (model DA-500); ISL ${ }^{\circledR}$ viscometer (model VH2); Tanaka $^{\circledR}$ Flash Point Tester (model APM-7); and Rancimat ${ }^{\circledR}$ (model 743).

\subsection{Transesterification Reaction}

Transesterification, also known as alcoholysis, is the reaction of a triglyceride of animal or vegetable origin with an alcohol in the presence of a catalyst, to give a mixture of fatty acid esters (biodiesel). ${ }^{21}$ Several process variables can affect the performance of alcoholysis including the reaction time, temperature, type and concentration of catalyst, stirring speed, ethanol:oil molar ratio, quality of the raw materials, ${ }^{7}$ water content and free fatty acid content. ${ }^{8}$ Experiments were performed in duplicate, and reaction conditions for each parameter is shown in table A.3 and A.4.

In the transesterification reaction the catalyst was added to the ethanol and the mixture was agitated for 5 minutes and then added to the corn oil. After the alkaline transesterification reaction, the system resulted in two phases with impure biodiesel being formed at the top and glycerin at the bottom. The biodiesel was removed from the mixture, adjusted the $\mathrm{pH}$ to near 7 and then washed 3 times with water at $80^{\circ} \mathrm{C}$. A high temperature of the washing water was necessary to solubilize and remove impurities. The yield was calculated from the stoichiometric relationship between the masses of biodiesel and corn oil, according to 
equation eq. A.1

$$
\text { Yield }=\frac{m_{\text {biodiesel }}}{m_{\text {oil }}} \times 95
$$

\subsection{Statistical Methods}

To determine the experimental conditions, as well as their simultaneous effects, which influence the yield of the transesterification reaction, screening of the variables reaction time, stirring speed, ethanol:oil molar ratio, type of catalyst, catalyst concentration and temperature was carried out through a $2^{6-2}$ fractional factorial design resulting in 16 experiments coded -1 (low level) and +1 (high level). After identifying the most significant variables, a central composite design (CCD) was used to determine the critical values for these variables, optimizing the experiment. The models were built using the program Statistica 7.0.

\section{Results and discussion}

Table A.1 gives the fatty acids composition of the corn oil in percentage terms. The three main fatty components are linoleic acid (C18:2), oleic acid (C18:1) and palmitic acid (C16:0), respectively, with relevant information in the literature..$^{22-24}$

Table A.1. Fatty acid content in corn oil ${ }^{24}$

\begin{tabular}{ccc}
\hline FATTY ACID & STRUCTURE & REFERENCE VALUES (\%) \\
\hline & C $<14$ & $<0.3$ \\
Myristic acid & C14:0 & $<0.1$ \\
Palmitic Acid & C16:0 & $9.0-14.0$ \\
Palmitoleic acid & C16:1 & $<0.5$ \\
Stearic Acid & C18:0 & $0.5-4.0$ \\
Oleic Acid (Omega 9) & C18:1 & $24.0-42.0$ \\
Linoleic Acid (Omega 6) & C18:2 & $34.0-62.0$ \\
Linolenic acid (Omega 3) & C18:3 & $<2.0$ \\
Arachidic acid & C20:0 & $<1.0$ \\
Eicosenoic Acid & C20:1 & $<0.5$ \\
Behenic acid & C22:0 & $<0.5$ \\
Lignoceric acid & C24:0 & $<0.5$ \\
\hline
\end{tabular}

To evaluate the quality of the commercial corn oil used, tests were carried out to determine some of its physicochemical properties and the results are shown in table A.2. These properties are directly related to the yield and quality of the biodiesel produced. In a literature review ${ }^{25}$ the viscosity and density were found $34.9 \mathrm{~mm}^{2} / \mathrm{s}$ the $311 \mathrm{~K}$ and $909.5 \mathrm{Kg} / \mathrm{m}^{3}$, respectively, these values show a good agreement with the information presented in table A.2, along with these properties the saponification index was similar to that presented by other researches that includes a value between 187-195 mg oleic acid / g confirming the characteristic of corn oil. ${ }^{26}$ 
de Lima A. P. et al.

Table A.2. Physicochemical properties of corn oil

\begin{tabular}{cccccc}
\hline PROPERTIES & UNITS & VALUE & STANDARD & METHODS \\
\hline Peroxide Index & $\mathrm{meq} \mathrm{Kg}^{-1}$ & 1.233 & 0.283 & ASTM D-1563 \\
Refractive Index $(25 \circ \mathrm{C})$ & - & 1.472 & 0.0006 & ASTM C-1648 \\
Refractive Index $(40 \circ \mathrm{C})$ & - & 1.467 & 0.0006 & ASTM C-1648 \\
Saponification index & $\mathrm{mg} \mathrm{oleic} \mathrm{acid} \mathrm{g}$ & & 190 & 2.5 & ASTM D-5558 \\
Acidity & $\mathrm{mg} \mathrm{KOH} \mathrm{g}^{-1}$ & 0.118 & 0.0027 & ASTM D-664 \\
Content Water & $\mathrm{mg} \mathrm{Kg}^{-1}$ & 732.9 & 14.9 & ASTM D-6304 \\
Specific gravity & $\mathrm{Kg} \mathrm{m}^{-3}$ & 918.5 & 0.0 & ASTM D-4052 \\
Viscosity & $\mathrm{mm}^{2} \mathrm{~s}^{-1}$ & 34.01 & 0.18 & ASTM D-445 e D-446 \\
Oxidative Stability & $\mathrm{hours}^{-10.23}$ & 0.06 & EN 14112 \\
\hline
\end{tabular}

Although there is no official specification for the production of biodiesel from oilseed crops, it is reported that high levels of acidity and humidity can reduce the yield of this reaction and that the acceptable values for the production of biodiesel are $2.0 \mathrm{mg}$ $\mathrm{KOH} / \mathrm{g}^{27}$ and a moisture content of less than $5000 \mathrm{mg} / \mathrm{kg}^{28}$ In the characterization of the corn oil obtained, an acid value of $0.118 \mathrm{mg}$ $\mathrm{KOH} / \mathrm{g}$ and a moisture content of 732.9 $\mathrm{mg} / \mathrm{kg}$ were obtained, therefore, this value these properties do not negatively affect the reaction yield. Table A.3 shows all tests according to the $2^{6-2}$ factorial design matrix and their performance values.

Table A.3. Matrix for the $2^{6-2}$ factorial design

\begin{tabular}{cccccccc}
\hline Test & Time & Rotation & Ethanol:oil & Type of & Catalytic & Temperature & Yield \\
\hline 1 & $30(-1)$ & $100(-1)$ & $9: 1(-1)$ & $\mathrm{NaOH}$ & $1.5(+1)$ & $55(+1)$ & 27.27 \\
2 & $30(-1)$ & $100(-1)$ & $9: 1(-1)$ & $\mathrm{NaOH}$ & $0.5(-1)$ & $35(-1)$ & 92.88 \\
3 & $30(-1)$ & $100(-1)$ & $12: 1(+1)$ & $\mathrm{KOH}(-1)$ & $0.5(-1)$ & $55(+1)$ & 96.18 \\
4 & $30(-1)$ & $100(-1)$ & $12: 1(+1)$ & $\mathrm{KOH}(-1)$ & $1.5(+1)$ & $35(-1)$ & 3.14 \\
5 & $30(-1)$ & $200(+1)$ & $9: 1(-1)$ & $\mathrm{KOH}(-1)$ & $0.5(-1)$ & $55(+1)$ & 96.13 \\
6 & $30(-1)$ & $200(+1)$ & $9: 1(-1)$ & $\mathrm{KOH}(-1)$ & $1.5(+1)$ & $35(-1)$ & 85.47 \\
7 & $30(-1)$ & $200(+1)$ & $12: 1(+1)$ & $\mathrm{NaOH}$ & $0.5(-1)$ & $35(-1)$ & 95.83 \\
8 & $30(-1)$ & $200(+1)$ & $12: 1(+1)$ & $\mathrm{NaOH}$ & $1.5(+1)$ & $55(+1)$ & 0.00 \\
9 & $60(+1)$ & $100(-1)$ & $9: 1(-1)$ & $\mathrm{KOH}(-1)$ & $1.5(+1)$ & $55(+1)$ & 87.14 \\
10 & $60(+1)$ & $100(-1)$ & $9: 1(-1)$ & $\mathrm{KOH}(-1)$ & $0.5(-1)$ & $35(-1)$ & 94.40 \\
11 & $60(+1)$ & $100(-1)$ & $12: 1(+1)$ & $\mathrm{NaOH}$ & $1.5(+1)$ & $35(-1)$ & $\sim 0.00$ \\
12 & $60(+1)$ & $100(-1)$ & $12: 1(+1)$ & $\mathrm{NaOH}$ & $0.5(-1)$ & $55(+1)$ & 91.37 \\
13 & $60(+1)$ & $200(+1)$ & $9: 1(-1)$ & $\mathrm{NaOH}$ & $1.5(+1)$ & $35(-1)$ & 49.64 \\
14 & $60(+1)$ & $200(+1)$ & $9: 1(-1)$ & $\mathrm{NaOH}$ & $0.5(-1)$ & $55(+1)$ & 91.53 \\
15 & $60(+1)$ & $200(+1)$ & $12: 1(+1)$ & $\mathrm{KOH}(-1)$ & $0.5(-1)$ & $35(-1)$ & 82.00 \\
16 & $60(+1)$ & $200(+1)$ & $12: 1(+1)$ & $\mathrm{KOH}(-1)$ & $1.5(+1)$ & $55(+1)$ & 55.88 \\
\hline
\end{tabular}

It can be seen in the Pareto chart in figure A.1 that the main negative effects were observed for type of catalyst, catalyst concentration and alcohol:oil molar ratio, 
indicating that for a better performance in terms of efficiency, these parameters must be kept at the low level (-1). On the other hand, we observed positive effects for stirring speed, time and temperature, which must be kept at the high level $(+1)$.

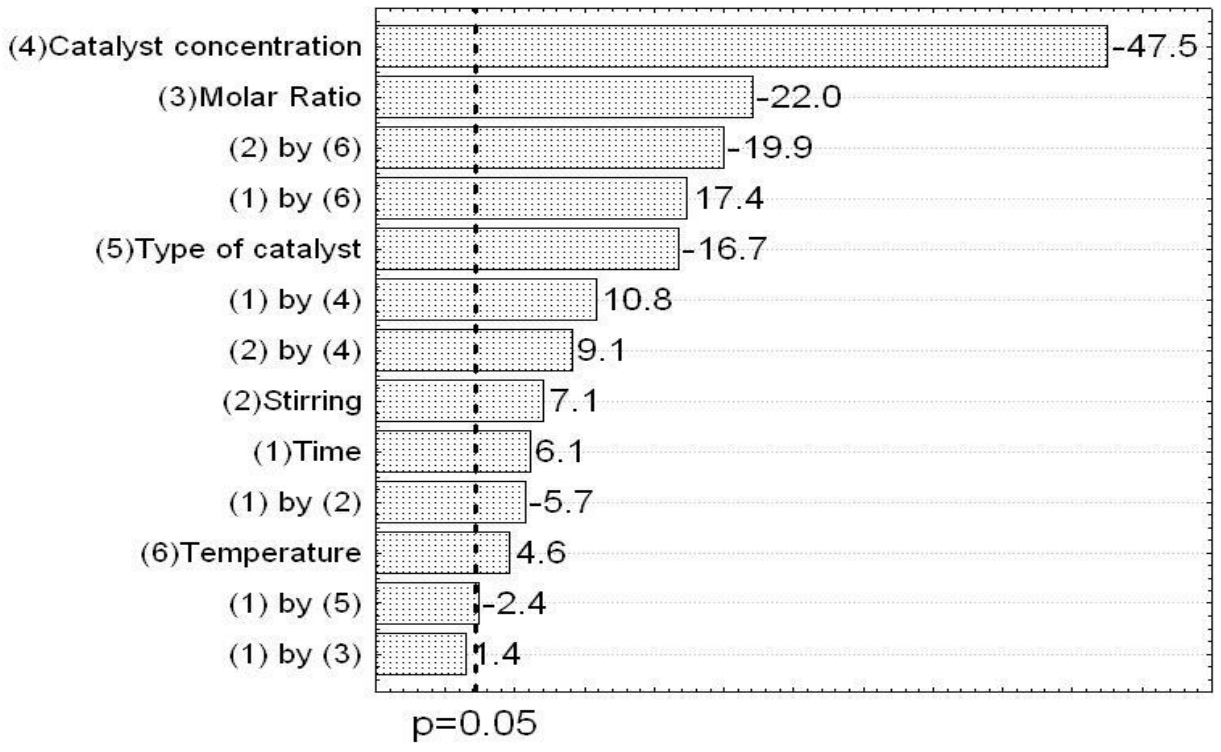

Figure A.1. Pareto chart of the resulting fractional factorial design evaluating the effects of each variable and their interactions on the yield of the transesterification of corn oil

The effects of the interactions of (1) time and (2) stirring, (1) time and (5) type of catalyst, and (1) time and (3) molar ratio on the yield of the transesterification were weaker than those of the main variables. As a result, these were disregarded in the subsequent statistical analysis.

The interaction of (2) stirring and (6) temperature is significant and negative, implying that the joint action of these two factors reverses the trends of the individual effects of the main variables, leading to reduced yields in the reaction. On the other hand, the interactions (1) time and (6) temperature, (1) time and (4) catalyst concentration, and (2) stirring and (4) catalyst concentration are significant and positive; causing, therefore, an increase in the yield of the reaction compared with the trends for each of the main individual effects.

Comparing the signs and magnitudes of the effects of the interactions (1) time and (6) temperature, and (2) stirring and (6) temperature, increasing yield of the reaction is associated with the conditions of the high levels for temperature and time, in agreement with the trend of their main individual effects. In the case of stirring speed, this was maintained at the low level to minimize the negative effect of the interaction of (2) stirring and (6) temperature, which was more significant than the main individual effects. The interpretation, even in the literature, of the interactions between the variables for methyl transesterification route are very poor $29-32$ and this deficit is even greater for ethylic route. $^{33}$

The type of catalyst chosen was $\mathrm{KOH}(-1)$. On evaluating the magnitudes of the other effects only the concentration of catalyst and the ethanol:oil molar ratio were used in the $C C D$, since the stirring speed, reaction time and temperature were fixed and thus did not significantly affect the yield of the reaction. The matrix of the central composite design is illustrated in table A.4. 
de Lima A. P. et al.

Table A.4. Matrix of central composite design.

\begin{tabular}{cccc}
\hline TESTS & CONCENTRATION OF CATALYST (\%) & $\begin{array}{c}\text { MOLAR RATIO } \\
\text { (ETHANOL: OIL) }\end{array}$ & YIELD (\%) \\
\hline 1 & & $10: 1(-1)$ & 66.30 \\
2 & $1.40(-1)$ & $12: 1(+1)$ & 73.77 \\
3 & $1.40(-1)$ & $10: 1(-1)$ & 64.01 \\
4 & $1.80(+1)$ & $12: 1(+1)$ & 50.30 \\
5 & $1.80(+1)$ & $11: 1(0)$ & 70.97 \\
6 & $1.32(-1.41)$ & $11: 1(0)$ & 64.80 \\
7 & $1.88(+1.41)$ & $9.6: 1(-1.41)$ & 72.27 \\
8 & $1.60(0)$ & $12.4: 1(+1.41)$ & 58.26 \\
9 & $1.60(0)$ & $11: 1(0)$ & 92.03 \\
10 & $1.60(0)$ & $11: 1(0)$ & 93.14 \\
11 & $1.60(0)$ & $11: 1(0)$ & 92.53 \\
12 & $1.60(0)$ & $11: 1(0)$ & 92.66 \\
13 & $1.60(0)$ & $11: 1(0)$ & 92.59 \\
\hline
\end{tabular}

The data obtained from the central composite design were also subjected to analysis of variance (ANOVA) and the F-test (confidence level 95\%), and the results are shown in table A.5. The model has a correlation coefficient $\left(R^{2}\right)$ of 0.9683 and the regression was statistically significant $\left(F_{\text {calculated }}<F_{\text {tabulated }}\right)$, in agreement with the results shown in figure A.2.

Table A.5. Results of analysis of variance and F-test for alkaline transesterification of corn oil via the ethylic route

\begin{tabular}{ccccccc}
\hline SOURCE OF & SQUARE & DEGREE OF & MEAN & $\boldsymbol{F}_{\text {tab }}$ & $\boldsymbol{F}_{\text {cal }}$ & $\mathbf{R}^{\mathbf{2}}$ \\
\hline Regression & 2369.67 & 5 & 473.93 & 36.63 & 4.39 & 0.9683 \\
Residuals & 77.63 & 6 & 12.94 & - & - & - \\
Pure error & 0.62 & 4 & 0.16 & - & - & - \\
\hline Total & 2447.30 & 11 & - & - & - & - \\
\hline
\end{tabular}




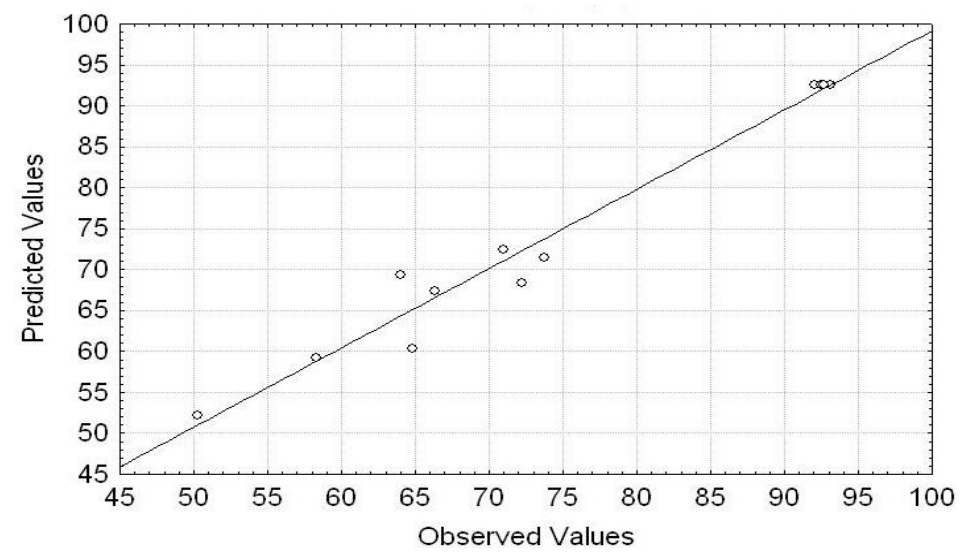

Figure A.2. Yield of biodiesel obtained from corn ethanol observed in the experiment versus the value predicted using the multivariate regression model

Figure A.3 shows the response surface obtained from the CCD according to the quadratic equation: Biodiesel yield $(\%)=$ $2884.60+1317.58 \times[\mathrm{KOH}$ content (\%)] $327.49 \times[\mathrm{KOH} \text { content }(\%)]^{2}+356.05 \times[$ Ratio $]-$ 14.41 Ratio $^{2}-26.47 \times[\mathrm{KOH}$ content (\%)] $\times[$ Ratio]. The solution of this quadratic equation represents the optimized process conditions, where maximum performance is obtained when the concentration of $\mathrm{KOH}$ is $1.56 \%$ mass/mass and the ethanol:oil molar ratio is 10.9:1. Works already done show that the molar ratio (alcohol:oil) and the concentration of catalyst are among the most important variables of transesterification. ${ }^{29,31}$ Although the chemical composition of oilseeds, in general, are somewhat similar, optimization studies of methyl route show a difference of $116 \%$ in the amount of catalyst used for the sunflower oil compared with rapeseed oil. $^{30,}{ }^{32}$ Using the same oilseed, rapeseed oil, there is a difference of $66 \%$ in the concentration of catalyst for the optimized condition, showing that in their study interval, the joint action of the other variables that influence the transesterification (table A.3), affect the performance differently. ${ }^{29,32}$

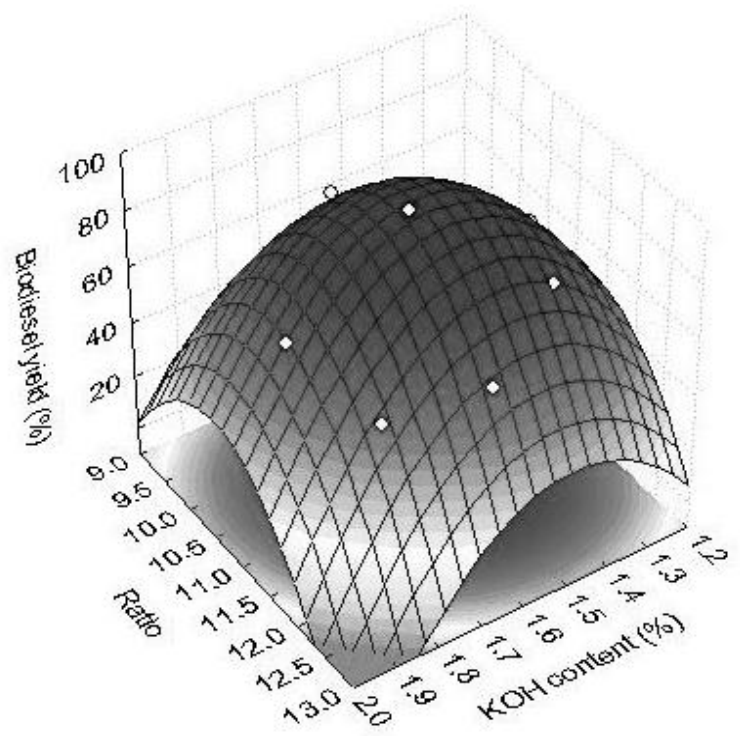

Figure A.3. Response surface for ethanol:oil molar ratio vs. catalyst concentration 
It can be noted from figure A.4, that the process of alkaline transesterification via the ethylic route is controllable in a catalyst concentration range of $1.3-1.8 \%(\mathrm{~m} / \mathrm{m})$ and with a molar ratio (ethanol:oil) between 9.9:1 and 11.9:1. Thus, the tolerance of the process is $1.56 \pm 0.25 \%$ mass $/$ mass for the catalyst concentration and 10.9:1 \pm 1 for the molar ratio (ethanol:oil). This information is important, especially for control the process, because it shows the strength that will define, for example, the type of controller and sensors to be installed, affecting directly the implementation, the feasibility process and of favoring the transesterification reaction, because this competes with the saponification reaction that is relatively fast, due to the availability of free fatty acid in the middle, which can be produced by the reaction of the hydroxide alkaline ions with ethanol in situ generating ethoxide and water, resulting in low yield reaction. Using high molar ratios for ethanol was obtained a low income, which may be due to solubilization of biodiesel and/or formation of emulsion in the reaction. However, as noted in table A.4, low concentrations of ethanol and/or concentration of catalyst are not guarantees of high yield, which explains the importance of applying the methodology of central composite design (CCD) for optimal process operating conditions.

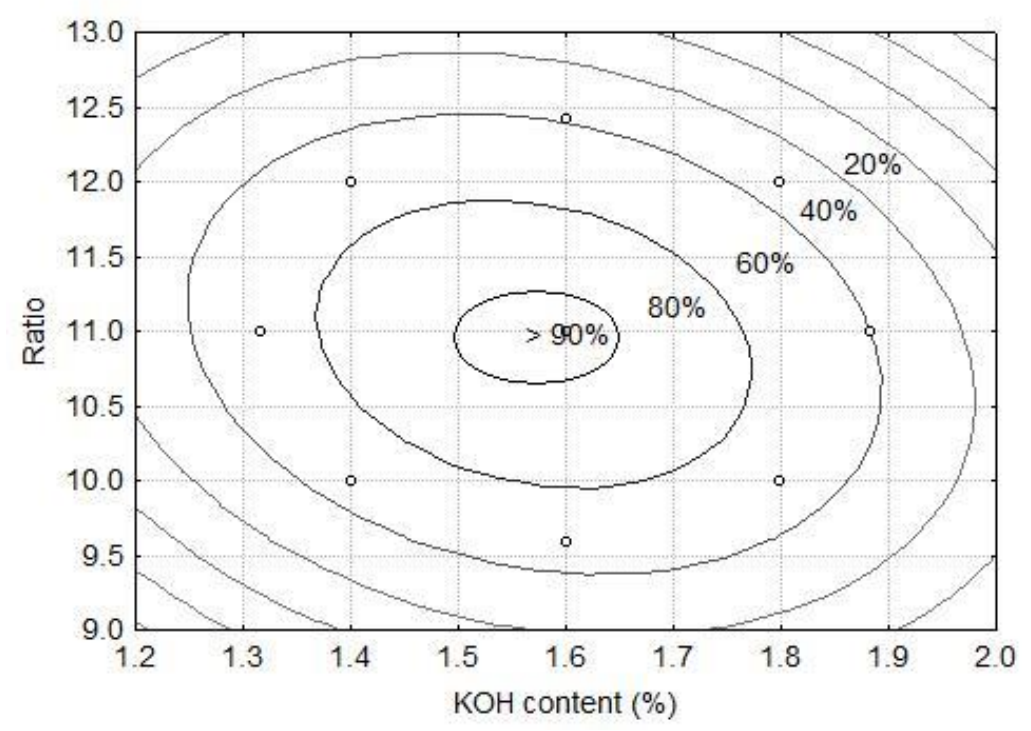

Figure A.4. Contour graph for the ethanol:oil molar ratio vs. the catalyst concentration

Comparing the results obtained by other researches for the same ethyl route, but using soybean oil (where the condition was optimized to 9:1 molar ratio (ethanol:oil) and $1.3 \% \mathrm{mass} / \mathrm{mass}$ for the concentration of catalyst $(\mathrm{NaOH})$, it appears that this molar ratio for the transesterification process using corn oil would be outside the control range (9.9:1 - 11.9:1). That would cause a sharp decrease in reaction yield (fig. 4), since the concentration of catalyst would limit the condition of process control; which is not interesting in the industrial point of view. ${ }^{33}$
Table A.6 shows some physicochemical properties of the biodiesel obtained in optimized conditions. It fits those parameters analyzed according to the specification parameters listed in Technical Regulation $n^{\circ}$ 14 / 2012 of the National Agency of Petroleum, Natural Gas and Biofuels (ANP), American Society of Testing and Materials ASTM D-6751 and Comité Européen de Normalisation EN 14214, except for the ANP in parameter containing water that has recently altered the limit of $500 \mathrm{mg} / \mathrm{kg}$ to $350 \mathrm{mg} / \mathrm{kg}$, specification valid for the period of $01 / 01 / 2013$ to $12 / 31 / 2013$. This 
parameter can be accommodated in the new specification by applying a new stage of drying. Can be observed in Table A.6 that were made the main quality standards required for producing biodiesel by the ANP,
ASTM and EN suggesting that biodiesel obtained has favorable conditions for direct use and / or as an additive to petroleum diesel. $^{34}$

Table A.6. Physicochemical properties of ethyl biodiesel produced by alkaline transesterification of corn oil

\begin{tabular}{cccc}
\hline Physical Properties & Units & Value & Method \\
\hline Saponification index & $\mathrm{mg} \mathrm{oleic} \mathrm{acid} \mathrm{g}^{-1}$ & 58 & ASTM D-5558 \\
Density & $\mathrm{kg} \mathrm{m}^{-3}$ & 875.1 & ASTM D-4052 \\
Content Water & $\mathrm{mg} \mathrm{kg}^{-1}$ & 470.2 & ASTM D-6304 \\
Acidity Index & $\mathrm{mg} \mathrm{KOH} \mathrm{g}^{-1}$ & 0.50 & ASTM D-664 \\
Cetane Index & & 51.5 & ASTM D-976 \\
Viscosity & $\mathrm{mm}^{2} \mathrm{~s}^{-1}$ & 4.6 & ASTM D-445 e D-446 \\
Oxidative Stability & $\mathrm{h}$ & 7.75 & EN 14112 \\
Flash Point & $\circ \mathrm{C}$ & 180 & ASTM D-93 \\
Total glycerin & $\%$ mass & 0.19 & ASTM D-6584 \\
Free glycerin & $\%$ mass & 0.02 & ASTM D-6584 \\
\hline
\end{tabular}

\section{Conclusions}

In this study, multivariate optimization methods were applied to determine the influence of the process variables on the alkaline transesterification reaction of corn oil via the ethylic route. The factorial design was efficient in the screening of significant variables applied in the optimization by the response surface method. The CCD resulted in optimized conditions being determined for the maximum biodiesel yield. From the equation obtained it is possible to predict the conditions required to obtain a higher yield and determine the robustness.

The methodology resulted in a simple technological model which is not limited, the efficiency of which was evaluated through the agreement between the physical and chemical parameters analyzed for biodiesel ethanol obtained from corn oil and the specification parameters listed in Technical Regulation $n^{\circ} 7$ / 2008 of the National Agency of Petroleum, Natural Gas and Biofuels
(ANP), American Society of Testing and Materials ASTM D-6751 and Comité Européen de Normalisation EN 14214.

\section{Acknowledgments}

The authors are grateful to FAPEMIG for their financial support of this project and by Teacher Doctor Manuel Gonzalo HernandezTerrones (in memory) for their help and support.

\section{References}

${ }^{1}$ Morón-Villarreyes, J. A.; C. Soldi; de Amorim, A. M.; Pizzolatti, M. G.; de Mendonça, A. P.; D'Oca, M. G. M.. Fuel 2007, 86, 1977. [CrossRef]

${ }^{2}$ Zhang, Y.; Stanciulescu, M.; Ikura, M. Appl. Catal. A 2009, 366, 176. [CrossRef] 
${ }^{3}$ Zanetti, F.; Vamerali, T.; Mosca, G. Ind. Crop. Prod. 2009, 30, 265. [CrossRef]

${ }^{4}$ Bhatti, H. N.; Hanif, M. A.; Qasim, M.; Ata ur, R. Fuel 2008, 87, 2961. [CrossRef]

${ }^{5}$ Lima, J. R. d. O.; da Silva, R. B.; Miranda, de Moura, E.; de Moura, C. V. R. Fuel 2008, 87, 1718. [CrossRef]

${ }^{6}$ Alamu, O. J.; Waheed, M. A.; Jekayinfa, S. O. Fuel 2008, 87, 1529. [CrossRef]

${ }^{7}$ Bi, Y.; Ding, D.; Wang, D. Bioresour. Technol. 2010, 101, 1220. [CrossRef] [PubMed]

${ }^{8}$ ANP, Anuário Estatístico Brasileiro do Petróleo, Gás Natural e Biocombustíveis, 2011, 1. [Link]

${ }^{9}$ Quintella, C. M.; Teixeira, L. S. G.; Korn, M. G. A.; Costa Neto, P. R.; Torres, E. A.; Castro, M. P.; Jesus, C. A. C.. Quim. Nova 2009, 32, 793. [CrossRef]

${ }^{10}$ da Costa, F. M.; Barreto, M.; Koshikumo, E.

S. M.; de Almeida, F. A. Summa Phytopathol. 2008, 34, 248. [CrossRef]

${ }^{11}$ Casa, R. T.; Moreira, E. N.; Bogo, A.; Sangoi, L.. Summa Phytopathol. 2007, 33, 353. [CrossRef]

${ }^{12}$ Duarte, A. P.; Carvalho, C. R. L.; Cavichioli, J. C. Bragantia 2008, 67, 759. [CrossRef]

${ }^{13}$ Suarez, P. A. Z.; Santos, A. L. F.; Rodrigues, J. P.; Alves, M. B. Quim. Nova 2009, 32, 768. [CrossRef]

${ }^{14}$ Sítio do Governo de Minas Gerais, Centro de Inteligência do Milho, 2010. [Link]

${ }^{15}$ Ministério do Desenvolvimento, Indústria e Comércio Exterior, 2010. [Link]

${ }^{16}$ Patil, P. D.; Deng, S. Fuel 2009, 88, 7, 1302. [CrossRef]

${ }^{17}$ Aued-Pimentel, S.; Kumagai, E. E.; Kus, M. M. M.; Caruso, M. S. F.; Tavares, M. and Zenebon, O. Ciênc. Tecnol. Aliment. 2009, 29, 646. [CrossRef]

${ }^{18}$ Demirbas, A. Prog. Energ. Combust. Sci. 2007, 33, 1. [CrossRef]

${ }^{19}$ Demirbas, A. Energ. Convers. Manag. 2008, 49, 125. [CrossRef]
${ }^{20}$ Gui, M. M.; Lee, K. T.; Bhatia, S. J. Supercrit. Fluids 2009, 49, 286. [CrossRef]

${ }^{21}$ Fukuda, H.; Kondo, A.; Noda, H. J. Biosci. Bioeng. 2001, 92, 405. [CrossRef] [PubMed]

2222 Balat, M. Energ. Convers. Manage. 2011, 52, 1479. [CrossRef]

${ }^{23}$ Dantas, M. B.; Albuquerque, A. R.; Barros, A. K.; Filho, M. G. R.; Filho, N. R. A.; Sinfrônio, F. S. M.; Rosenhaim, R.; Soledade, L. E. B.; Santos, I. M. G.; Souza, A. G. Fuel 2011, 90, 773. [CrossRef]

${ }^{24}$ Agência Nacional de Vigilância Sanitária, 2010. [Link]

${ }^{25}$ Demirbas, A. Prog. Energ. Combust. Sci. 2005, 31, 466. [CrossRef]

${ }^{26}$ Giannelos, P. N.; Sxizas, S.; Lois, E.; Zannikos, F.; Anastopoulos, G. Ind. Crop. Prod. 2005, 22, 193. [CrossRef]

${ }^{27}$ Canakci, M.; Gerpen, J. V. Am. Soc. Agric. Biol. Eng. 2001, 44, 1429. [Link]

${ }^{28}$ Cavalcante, K. S. B.; Penha, M. N. C.; Mendonça, K. K. M.; Louzeiro, H. C.; Vasconcelos, A. C. S.; Maciel, A. P.; de Souza, A. G.; Silva, F. C.. Fuel 89, 2010, 1172. [CrossRef]

${ }^{29}$ Yuan, X.; Liu, J.; Zeng, G.; Shi, J.; Tong, J.; Huang, G. Renew. Energ. 2008, 33, 1678. [CrossRef]

${ }^{30}$ Vicente, G.; Coteron, A.; Martinez, M.; Aracil, J. Ind. Crop. Prod. 1998, 8, 29. [CrossRef]

${ }^{31}$ Rashid, U.; Anwar, F.; Ashraf, M.; Saleem, M.; Yusup, S. Energ. Convers. Manage. 2011, 52, 3034. [CrossRef]

${ }^{32}$ Ferella, F.; Di Celso, G. M.; De Michelis, I.; Stanisci, V.; Vegliò, F. Fuel 89, 36. [CrossRef]

${ }^{33}$ Silva, G. F.; Camargo, F. L.; Ferreira, A. L. O. Fuel Process. Technol. 2011, 92, 407. [CrossRef]

${ }^{34}$ Lôbo, I. P.; Ferreira, S. L. C.; Cruz, R. S. Quim. Nova 2009, 32, 1596. [CrossRef] 